\title{
Mercury in air and plant specimens in herbaria: A pilot study at the MAF Herbarium in Madrid (Spain)
}

\author{
R. Oyarzun ${ }^{\mathrm{a}, *}$, P. Higueras ${ }^{\mathrm{b}}$, J.M. Esbrí $^{\mathrm{b}}$, J. Pizarro $^{\mathrm{c}}$ \\ a Departamento de Cristalografia y Mineralogía, Facultad de Ciencias Geológicas, Universidad Complutense, 28040 Madrid, Spain \\ b Departamento de Ingeniería Geológica y Minera, Escuela Universitaria Politécnica de Almadén, \\ Universidad de Castilla-La Mancha, Plaza M. Meca 1, 13400 Almadén, Spain \\ c Departamento de Biología Vegetal II, Facultad de Farmacia, Universidad Complutense, 28040 Madrid, Spain
}

Received 6 March 2007; received in revised form 23 May 2007; accepted 23 May 2007

Available online 27 June 2007

\begin{abstract}
We present data from a study of mercury concentrations in air and plant specimens from the MAF Herbarium in Madrid (Spain). $\mathrm{Hg}$ (gas) emissions from old plant collections treated with mercuric chloride $\left(\mathrm{HgCl}_{2}\right)$ in herbaria may pose a health risk for staff working in installations of this type. This is an issue not yet properly addressed. Plants that underwent insecticide treatment with $\mathrm{HgCl}_{2}$ at the MAF Herbarium until the mid 1970s have persistent high concentrations of $\mathrm{Hg}$ in the range $1093-11,967 \mu \mathrm{g} \mathrm{g}^{-1}$, whereas untreated specimens are in the range of $1.2-4.3 \mu \mathrm{g} \mathrm{g}^{-1}$. The first group induces high concentrations of Hg (gas) in the main herbarium room, with seasonal variations of 404-727 $\mathrm{ng} \mathrm{m}^{-3}$ (late winter) and 748-7797 $\mathrm{ng} \mathrm{m}^{-3}$ (early summer) (baseline for $\mathrm{Hg}: 8 \mathrm{ng} \mathrm{m}^{-3}$ ). A test survey at another herbarium in Madrid showed even higher concentrations of $\mathrm{Hg}$ (gas) above $40,000 \mathrm{ng}$ $\mathrm{m}^{-3}$. The World Health Organization guidelines for chronic exposure to $\mathrm{Hg}$ (gas) are estimated at a maximum of $1000 \mathrm{ng}^{-3}$. While staff was aware of the existence of $\mathrm{HgCl}_{2}$ treated plants (the plant specimen sheets are labelled as 'poisoned'), they had no knowledge of the presence of high $\mathrm{Hg}$ (gas) concentrations in the buildings, a situation that may be relatively common in herbaria. (C) 2007 Elsevier B.V. All rights reserved.
\end{abstract}

Keywords: Mercury gas; Mercuric chloride, Herbaria; Plants, Health risk

\section{Introduction}

A classic threat to preservation of herbarium specimens are insects and fungi, for which a series of chemical deterrents were used in the past, among them mercuric chloride $\left(\mathrm{HgCl}_{2}\right)$. Mercuric chloride was widely used until the 1970s, and even the early 1980 s in some herbaria (Clark, 1986), when health risks made it unsuitable for specimen preservation. However, given that many herbaria are much older that this, an important

\footnotetext{
* Correponding author.

E-mail address: oyarzun@geo.ucm.es (R. Oyarzun).
}

number of plant specimens in herbaria worldwide are contaminated with mercury. To our knowledge few scientific studies (e.g., Purewal, 2001) have been conducted in herbaria to determine the extent of $\mathrm{Hg}$ (gas) contamination, and only one of them (Hawks et al., 2004) includes measurements of gaseous mercury with continuous $\mathrm{Hg}$ (gas) measurements, real-time monitoring. A pioneer work on $\mathrm{Hg}$ (gas) in herbaria was conducted by Briggs et al. (1983), who stated that: "In the light of our experience, it seems likely that other institutions will wish to study the concentration of mercury vapour in their rooms and collections especially if collections are housed in tightly closed unventilated 
cupboards. It may be that a herbarium has discontinued the practice of treating its specimens with mercuric chloride but we stress the important point that historic and other collections may have been poisoned with mercuric chloride in the past, and will currently be releasing metallic mercury vapour into the atmosphere, perhaps in sufficient quantities to constitute a health risk".

Given the experience of our research group on mercury distribution and speciation, gained from studies on rocks, minerals, soils, plants, and waters (e.g., Higueras et al., 2005, 2006; Molina et al., 2006), we carried out a pilot study in one of the oldest Spanish herbaria: the Complutense University, Faculty of Pharmacy MAF Herbarium, founded in 1892, and hosted by the Department of Plant Biology II (Fig. 1a). The main room of the MAF Herbarium contains one of the oldest and most comprehensive collections of scientific plant specimens in Spain, with over 160,000 sheets, including the 18th century historical collection of Pourret. $\mathrm{HgCl}_{2}$

\section{a Department of Plant Biology II (Biología Vegetal II)}

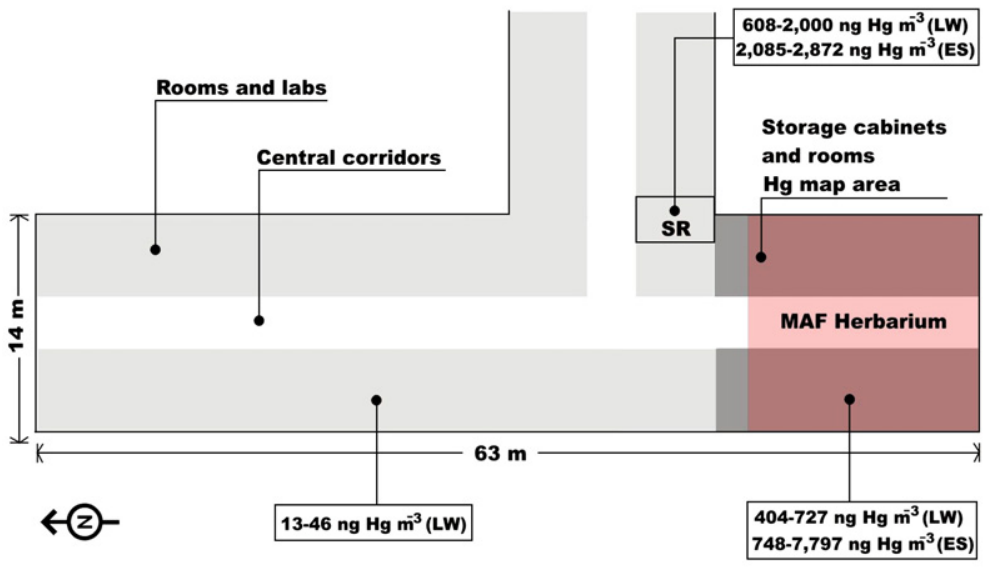

The MAF Herbarium
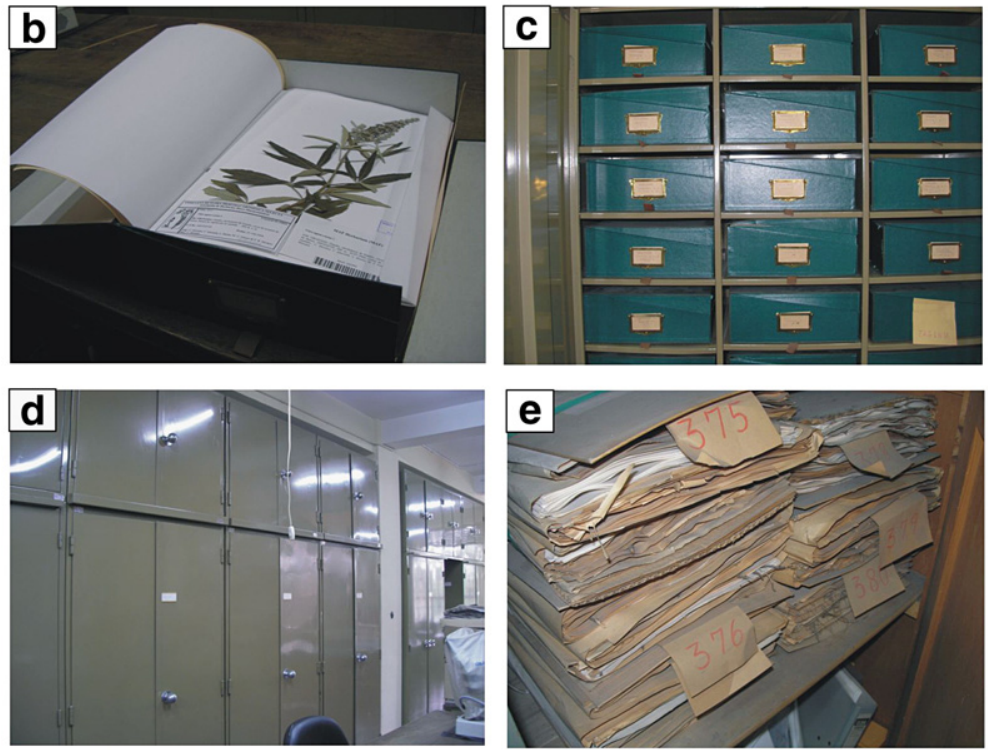

Fig. 1. The MAF Herbarium: a) plan view of the department, herbarium and Hg concentrations (ES: early summer, LW: late winter; SR: storage room); b) plant specimens; c) card boxes for storing plant specimen sheets; d) metal cabinets; e) older plant specimen sheets kept in poorly sealed wooden cabinets (southern sector of MAF). 
plant specimen treatment was abandoned at the MAF by the mid 1970s, and at present the standard procedure involves the freezing of specimens at $-30{ }^{\circ} \mathrm{C}$ for $48 \mathrm{~h}$.

\section{Materials and methods}

The study was conducted in 2006 at the MAF Herbarium and adjacent rooms and labs of the Department of Plant Biology II (Fig. 1a). We conducted measurements of mercury in air and plant specimens from herbarium sheets (Fig. 1b) kept in cardboard boxes (Fig. 1c) stored in metallic and wooden cabinets (Fig. 1d, e). Both older $\left(\mathrm{HgCl}_{2}\right.$ treated) and modern specimens were sampled for comparison. To assess seasonal variability we conducted two surveys for $\mathrm{Hg}$ (gas). Gaseous mercury was measured along perpendicular profiles, using a tape to determine the exact location of sampling stations in the main room of the MAF Herbarium (Fig. 2). Other measurements were conducted in laboratories and rooms from the rest of the department, giving a total of 38 stations. The first survey for gaseous mercury was conducted in late winter ( 7 th of March), whereas the second one was done in early summer (28th of June). Given that the building lacks an air conditioning system, temperatures oscillated between $23{ }^{\circ} \mathrm{C}$ (first survey) and $31{ }^{\circ} \mathrm{C}$ (second survey). An additional station was placed outside the faculty building (Patio Lázaro Ibiza) to obtain a baseline value for $\mathrm{Hg}$ (gas), which yielded a concentration of $8 \mathrm{ng} \mathrm{m}^{-3}$. The surveys were carried out with a LUMEX RA-915+ analyzer for continuous $\mathrm{Hg}$ (gas) measurements. This instrument is a portable multifunctional atomic absorption spectrometer with Zeeman background correction, which eliminates the effect of interfering impurities. It is a high sensitivity and selectivity instrument that does not require gold amalgam pre-concentration and subsequent regeneration steps. This enables the user to conduct real-time monitoring (US EPA, 2007). The analytical procedure is based on Zeeman atomic absorption spectrometry with high frequency modulation of light polarization (ZAASHFM). Application of Zeeman background correction and a multipath analytical cell provide high selectivity and sensitivity of measurements. The instrument allows determination of $\mathrm{Hg}$ in air directly with an ultra low detection limit in real time. This detection limit is governed by shot noise and equals $2 \mathrm{ng} \mathrm{m}^{-3}$ (average measuring time $=5 \mathrm{~s}$ ) and $0.3 \mathrm{ng} \mathrm{m}^{-3}$ (average measuring time $=30 \mathrm{~s}$ ) for mercury determination in air. The dynamic range covers four orders of magnitude $(2-30,000 \mathrm{ng}$ $\mathrm{m}^{-3}$ ). The real time measurements are made with visualization of the process on a digital display (Sholupov and Ganeyev, 1995). Addition of the RP-91C (pyrolysis) attachment allows $\mathrm{Hg}$ measurements in solid samples. This attachment was used for the analyses of dried plants at the laboratories of the Almadén School of Mines (ASM; Universidad de Castilla-La Mancha). Mercury in the samples is converted from a bound state to the atomic state by thermal decomposition in a two-section atomizer. As a first step the sample is vaporized and the mercury

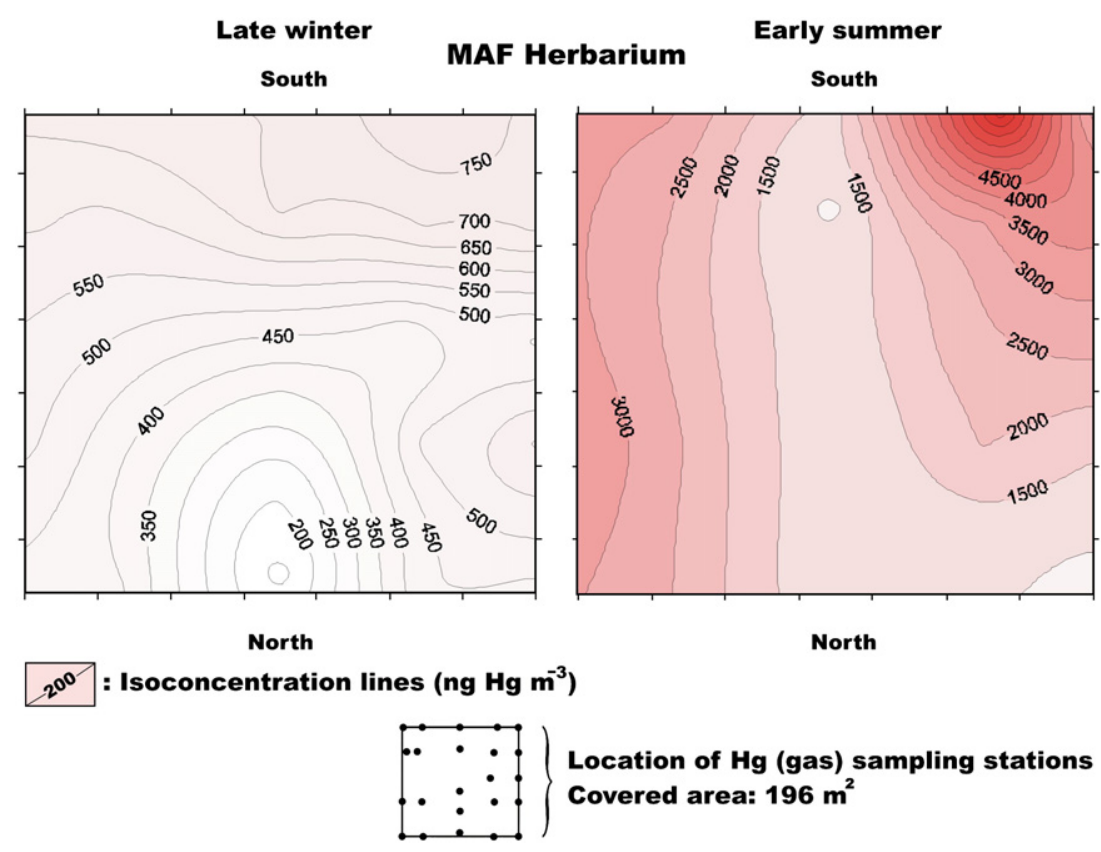

Fig. 2. Point linear kriging of $\mathrm{Hg}$ (gas) concentrations in the MAF Herbarium in late winter and early summer (program: Surfer 8). 
compounds are partly decomposed. This is followed by heating to $800^{\circ} \mathrm{C}$, when the mercury compounds become fully decomposed, whereas organic compounds and carbon particles are catalytically transformed to carbon dioxide and water. The analysis takes 1-2 min. Detection limit for the dry plant samples is $2 \mu \mathrm{g} \mathrm{kg}^{-1}$. Direct atomic absorption mercury determination in samples with a complex matrix such as plants is complicated because of the presence of organic compounds. However, the use of background correction in the Zeeman atomic absorption mercury spectrometer RA-915+ overcomes the problem (Molina et al., 2006). Quality control at the laboratory was done by analyzing duplicate samples to check precision: $8.8 \%$ for the set of studied samples. Accuracy is obtained at the ASM lab by using certified standards: (SRM) NIST 2710, (SRM) NIST 2711, (SRM) NIST 1515 and BCR 146R. Variation between the certified value of (SRM) NIST 1515 (apple leaves; $44 \mathrm{ng} \mathrm{g}^{-1}$ ) and those obtained at the AMS lab (after 10 runs) was $5.9 \%$.

\section{Results}

The results from the surveys show two main facts: 1) $\mathrm{Hg}$ (gas) concentrations in the main room of the MAF Herbarium in early summer were much higher $\left(748-7797 \mathrm{ng} \mathrm{m}^{-3} ; n=23\right.$; mean $\left.=2479.3 ; \mathrm{SD}=1446.1\right)$ than those measured in late winter $\left(404-727 \mathrm{ng} \mathrm{m}^{-3}\right.$; $n=23$; mean $=529.0 ; \mathrm{SD}=168.8$ ) (Figs. 1a and 2). The results were treated with the Surfer 8 program to assess the spatial variability of data by point linear kriging (Fig. 2). In both cases (late winter and early summer) the maximum values concentrated in the southwest corner of the main room where older and loosely stored plant specimens are kept in wooden, poorly sealed cabinets (Figs. 1e and 2). Results from other rooms and labs of the department displayed much lower $\mathrm{Hg}$ (gas) concentrations, in the range of 13-46 $\mathrm{ng} \mathrm{m}^{-3}$ (west-facing wing of the department) (Fig. 1a). However, there is one major exception: the small storage room (SR) (for plant specimens) with concentrations of $\mathrm{Hg}$ (gas) up to $2000 \mathrm{ng} \mathrm{m}^{-3}$ (winter) and $2872 \mathrm{ng} \mathrm{m}^{-3}$ (summer) (Fig. 1a). Rooms adjacent to this site display $\mathrm{Hg}$ (gas) concentrations in the range of 99-169 $\mathrm{ng} \mathrm{m}^{-3}$ (winter) and a summer maximum of $545 \mathrm{ng} \mathrm{m}^{-3}$.

Mercury concentrations in desiccated tissues from plant specimens showed contrasting results (Table 1). The older plant specimens usually had much higher concentrations that those that were accessioned from the mid 1970s onwards. The youngest-studied specimen with high $\mathrm{Hg}$ concentration was Rubus caflishii (MAF 98898), which was prepared for conservation in 1973 (Hg: $5487 \mu \mathrm{g} \mathrm{g}^{-1}$ ), whereas the highest concen-
Table 1

Mercury in desiccated plants (Department of Plant Biology II)

\begin{tabular}{llll}
\hline Plant & MAF & Year (1) & $\mathrm{Hg}\left(\mu \mathrm{g} \mathrm{g}^{-1}\right)$ \\
\hline Marchantia polymorpha & $(2)$ & 1800 & $11,966.7$ \\
Senecio tournefortii & 63356 & 1892 & 1093.3 \\
Senecio tournefortii & 64981 & 1904 & 4100.0 \\
Malus baccata & 66085 & 1906 & 2.7 \\
Malus baccata & 66086 & 1906 & 3.7 \\
Malus baccata & 66200 & 1907 & 3.0 \\
Senecio tournefortii & 14833 & 1922 & 4650.0 \\
Rumex acetosella & 71651 & 1944 & 1450.0 \\
Geum sylvaticum & 71788 & 1944 & 2625.0 \\
Statice ferulacea & 71281 & 1961 & 5851.2 \\
Jasione montana & $(3)$ & 1963 & 2255.0 \\
Hypericum linariifolium & $(3)$ & 1963 & 3290.0 \\
Rubus caflishii & 98898 & 1973 & 5486.7 \\
Reynoutria sachalinensis & 94821 & 1976 & 4.3 \\
Reseda lutea & 165224 & 2000 & 4.0 \\
Hippocrepis commutata & 165225 & 2000 & 1.5 \\
Galium verum & 165231 & 2000 & 1.2 \\
Scorzonera angustifolia & 165232 & 2000 & 2.5
\end{tabular}

1: Corresponds to the year in which the plant was collected. 2. Pourret Collection. 3. Plants kept in the storage room (SR) (Fig. 1a).

tration was found in a very old specimen from 1800 (Marchantia polymorpha; Pourret Collection) (Hg: $11,967 \mu \mathrm{g} \mathrm{g}^{-1}$ ). Modern specimens (from 1976 onwards) had $\mathrm{Hg}$ concentrations below $5 \mu \mathrm{g} \mathrm{g}^{-1}$. However, some of the older specimens, such as Malus baccata (MAF 66200), may also have low concentrations $\left(<4 \mu \mathrm{g} \mathrm{g}^{-1}\right)$, which indicates that not all plants were treated with mercuric chloride.

\section{Discussion and conclusions}

Despite the large number of herbaria around the world, and far more importantly, the thousands of technicians and researchers who work in them (New York Botanical Garden, 2007), little attention in the published literature in environmental journals has been paid to the $\mathrm{Hg}$ derived health risks in these workplaces. There is no need here to highlight the toxicity of the different mercurial species, or the potential risks that this metal poses to human life, which are well known facts. However, most of the attention has been focussed on mercury derived from industrial and mining activities. The same applies to the different mercury species. For example, while there is a widespread public concern regarding the presence of methylmercury $\left(\mathrm{CH}_{3} \mathrm{Hg}^{+}\right)$in seafood, the public little realizes the potential health risks derived from the presence of gaseous mercury. The World Health Organization (WHO, 2000) indicates that concentrations of $\mathrm{Hg}$ in air in the range of 15,000$30,000 \mathrm{ng} \mathrm{m}^{-3}$ may have effects on human physiology 
(tremors, renal tubular effects, change in plasma enzymes, and others). However, the same organization recognizes that these figures are rough estimates and that it seems appropriate to use an uncertainty factor of 20; thus, an estimated guideline for mercury concentration in air would be $1 \mu \mathrm{g} \mathrm{m}^{-3}\left(1000 \mathrm{ng} \mathrm{m}^{-3}\right)$ (WHO, 2000). The US EPA (2007) (Region 5) recommends the following: if $\mathrm{Hg}$ (gas) concentrations are between $1-$ $10 \mu \mathrm{g} \mathrm{m}^{-3}\left(1000-10,000 \mathrm{ng} \mathrm{m}^{-3}\right)$, relocation of residents should be scheduled as soon as possible. For concentrations above $10 \mu \mathrm{g} \mathrm{m}^{-3}\left(>10,000 \mathrm{ng} \mathrm{m}^{-3}\right)$, residents should be relocated immediately. As shown in Fig. 2, Hg (gas) concentration in the MAF during early summer exceeds the WHO (2000) and US EPA (2007) recommendations. On the other hand, the current US Occupational Safety and Health Administration permissible exposure limit for $\mathrm{Hg}$ (gas) is $0.1 \mathrm{mg} \mathrm{m}^{-3}$ $\left(100,000 \mathrm{ng} \mathrm{m}^{-3}\right)$ of air as a ceiling limit (US OSHA, 2007). Besides, the National (US) Institute for Occupational Safety and Health (NIOSH) has established a recommended exposure limit for $\mathrm{Hg}$ (gas) of $0.05 \mathrm{mg}$ $\mathrm{m}^{-3}\left(50,000 \mathrm{ng} \mathrm{m}^{-3}\right)$ as a time weighted average (TWA) for up to a 10-hour workday and a 40-hour workweek (US OSHA, 2007). The American Conference of Governmental Industrial Hygienists has assigned to $\mathrm{Hg}$ (gas) a threshold limit value of $0.025 \mathrm{mg} \mathrm{m}^{-3}\left(25,000 \mathrm{ng} \mathrm{m}^{-3}\right)$ as a TWA for a normal 8-hour workday and a 40-hour workweek (US OSHA, 2007). The minimum risk level (MRL) for chronic inhalation of $\mathrm{Hg}$ (gas) is $0.0002 \mathrm{mg} \mathrm{m}^{-3}\left(200 \mathrm{ng} \mathrm{m}^{-3}\right)$ (US OSHA, 2007). An MRL is an estimate of the daily human exposure to a hazardous substance that is likely to be without appreciable risk of adverse (non-cancer) health effects over a specified duration of exposure. The US EPA reference concentration for inhalation is calculated to be $0.0003 \mathrm{mg} \mathrm{m}^{-3}$ (300 $\mathrm{ng} \mathrm{m}^{-3}$ ) (TWA) (US OSHA, 2007).

$\mathrm{Hg}$ (gas) concentrations above the range $10^{3}-10^{4} \mathrm{ng}$ $\mathrm{m}^{-3}\left(0.001-0.01 \mathrm{mg} \mathrm{m}^{-3}\right)$ are usually found in mercury mining sites or mercury metallurgical installations (e.g., Ferrara et al., 1998; Higueras et al., 2005, 2006; Kotnik et al., 2005). In this respect, people subjected to working conditions involving high concentrations of $\mathrm{Hg}$ (gas), may develop a chronic disease called hydrargyrism (=hydrargyria, mercurialism) (e.g. Damrau, 1990), which was observed, for example, among the miners from the mercury mines of Almadén (Spain) (Menéndez, 1996).

For comparative studies only, we conducted a second study at the largest herbarium in Spain, the Real Jardín Botánico Herbarium (MA), on the 4th of July 2006, with a room temperature of $26^{\circ} \mathrm{C}$. The MA is larger than the MAF, better equipped, and the main room is well sealed.
A profile along the main room produced surprising results, with instrumental readings indicating $\mathrm{Hg}$ (gas) concentrations in air between 40,370-41,340 $\mathrm{ng} \mathrm{m}^{-3}$. These values are above the instrument's dynamic range of 2-30,000 $\mathrm{ng} \mathrm{m}^{-3}$, which indicates that these figures should be taken as minimum concentrations only. Meanwhile, a station located outside the building gave a baseline value for $\mathrm{Hg}$ (gas) of 3-6 $\mathrm{ng} \mathrm{m}^{-3}$, whereas a coffee room adjacent to the baseline station gave a reading of $12 \mathrm{ng} \mathrm{m}^{-3}$. We suggest that one of the reasons for the extremely large $\mathrm{Hg}$ concentrations in the MA Herbarium is to be found in the excellent insulation of the facilities. Conversely, the MAF Herbarium is located within an old building, where insulation is poor and therefore, air easily circulates in and out, lowering $\mathrm{Hg}$ (gas) concentrations in the main room.

A discussion of the results with the MA authorities led to the adoption of several measures. A second survey was performed on the 10th of July, which confirmed the previous results. This was followed by a simple test of air circulation that involved keeping all the windows open and forcing ventilation with electric table fans for $15 \mathrm{~min}$. This resulted in a remarkable decrease in $\mathrm{Hg}$ concentration to less than a half, which suggests that continuous forced ventilation and extraction of air from the main herbarium room could improve habitability conditions. Our survey prompted both an additional assessment study focused on health of the staff at MA and the installation of a forced ventilation system that is currently underway. Ventilation also diminished $\mathrm{Hg}$ (gas) concentrations at the MAF, where air circulation in the most contaminated (southern) sector led to a $70 \%$ decrease in summer, and $90 \%$ in winter.

Two aspects of the problem remain to be discussed: 1) the direct relationship between temperature and $\mathrm{Hg}$ (gas) concentrations; and 2) why mercuric chloride $\left(\mathrm{HgCl}_{2}\right)$, a rather stable chemical compound at room temperature, gives rise to $\mathrm{Hg}^{0}$ (gas). Two major factors control the $\mathrm{Hg}$ (gas) emissions from a given substrate: light and temperature (Gustin et al., 2002; Scholtz et al., 2003). Light is the initial dominant process controlling $\mathrm{Hg}$ (gas) emissions because of the photolytic reduction of $\mathrm{Hg}^{2+}$ to $\mathrm{Hg}^{0}$. Given that $\mathrm{Hg}$ is a volatile element, after a pool of available $\mathrm{Hg}^{0}$ is developed, gaseous $\mathrm{Hg}$ release becomes the dominant process, which is facilitated by increasing temperatures (Gustin et al., 2002). This would explain why $\mathrm{Hg}$ (gas) increased in the early summer survey. However, given that the plant specimens remain stored in cabinets most of the time (Fig. 1d), and therefore no light reaches them, extensive photolytic reduction can hardly explain the conversion from $\mathrm{HgCl}_{2}$ (solid) to $\mathrm{Hg}^{0}$ (gas). The material safety data sheet for 
$\mathrm{HgCl}_{2}$ (MSDS, 2007) indicates that this compound slowly decomposes to metallic $\mathrm{Hg}$ in the presence of organic matter and sunlight, and becomes volatile at $300^{\circ} \mathrm{C}$. However, as stated before, no light usually reach the plant specimens, and obviously, a temperature of $300{ }^{\circ} \mathrm{C}$ is out of the question. Although a full discussion of this conversion goes far beyond the scope of this work, we suggest the following explanation. Mercuric chloride may undergo decomposition via the reaction $\mathrm{HgCl}_{2} \rightarrow \mathrm{Hg}^{2++} 2 \mathrm{Cl}^{-}$(Lin and Pehkonen, 1999). Subsequently, bacteria can reduce the ionic form of mercury into its volatile form $\left(\mathrm{Hg}^{0}\right)$ via enzymatic reduction (Kannan and Krishnamoorthy, 2006). NADPH (nicotinamide adenine dinucleotide phosphate), and to a lesser extent NADH (nicotinamide adenine dinucleotide), act as electron donors for the enzymatic reduction of $\mathrm{HgCl}_{2}$, which is followed by vaporization to $\mathrm{Hg}$ (gas) after reduction (Komura et al., 1971). One may argue that the dry environment of cabinets is not suitable for bacterial activity, however, most gram-positive and many gramnegative bacteria can survive for months on dry surfaces (Kramer et al., 2006). Furthermore, the presence of bacteria has been even reported from the driest core of the Atacama Desert, a place that NASA researchers consider as an analog environment for Mars, and have used this environment as proving grounds for future Mars instrumentation aiming to detect signatures of life (Lester et al., 2007). A complementary although partial explanation may be provided by the fact that plant specimens are actually exposed to the light while being studied by researchers. However, this does not happen at a massive scale, because at any given time only a few specimens are simultaneously exposed to the light.

As a last comment we would like to highlight the following. Both the MA and MAF staff members were unaware of the anomalous $\mathrm{Hg}$ (gas) concentrations present in the buildings, and it is our opinion that this case may be far more common than we initially thought. The danger posed by $\mathrm{HgCl}_{2}$ (a highly toxic compound on its own) and other pollutants has been recognized in herbaria (e.g., Bauer and Fuortes, 1999; Rader and Ison, 1999; Purewal, 2001). However, without systematic environmental studies for $\mathrm{Hg}$ (gas) in herbaria, no sound assessments of the extent and intensity of mercury contamination can be made. Besides, given the WHO (2000) and US EPA (2007) recommendations, the chosen analytical procedures should be sensitive enough to measure $\mathrm{Hg}$ (gas) concentrations at least as low as $1000 \mathrm{ng} \mathrm{m}^{-3}\left(1 \mathrm{gg} \mathrm{m}^{-3}\right)$. Although older plant collections that were treated with $\mathrm{HgCl}_{2}$ are usually labelled as 'poisoned', the risks may go far beyond the handling of these specimens. As shown in this work, $\mathrm{Hg}$ eventually passes into the air in its gaseous form, which can lead to unacceptable concentrations of the element for those who work on a permanent basis in herbaria.

\section{Acknowledgements}

This research was funded by Grant PPQ2003-01902 (Spanish Ministry of Education and Science). We thank Montserrat Gutiérrez (UCM), and Gonzalo Nieto and Mauricio Velayos (RJB-CSIC) for allowing us to perform the surveys in the MAF and MA herbaria. This paper benefited from the comments of anonymous reviewers and Associate Editor Jim Bennett.

\section{References}

Bauer EP, Fuortes LJ. An assessment of exposure to mercury and mercuric chloride from handling treated herbarium plants. Vet Human Toxicol 1999;41:154-6.

Briggs D, Sell PD, Block M, I'Ons RD. Mercury vapour: a health hazard in herbaria. New Phytologist 1983;94:453-7.

Clark S. Preservation of herbarium specimens: an archive conservators approach. Taxon 1986;35:675-81.

Damrau J. Zur therapie quecksilberinduzierter organschaden. Z Gesamte Inn Med 1990;45:89-92.

Ferrara R, Maserti E, Andersson M, Edner H, Ragnarson P, Svanberg S, Hernández A. Atmospheric mercury concentrations and fluxes in the Almadén district (Spain). Atmos Env 1998;32:3897-904.

Gustin MS, Biester H, Kim CS. Investigation of the light-enhanced emission of mercury from naturally enriched substrates. Atmos Env 2002;36:3241-54.

Hawks C, Makos K, Bell D, Wambach PF, Burroughs GE. An inexpensive method to test for mercury vapor in herbarium cabinets. Taxon 2004;53:783-7.

Higueras P, Oyarzun R, Lillo J, Oyarzún J, Maturana H. Atmospheric mercury data for the Coquimbo region, Chile: influence of mineral deposits and metal recovery practices. Atmos Env 2005;39: 7587-96.

Higueras P, Oyarzun R, Lillo J, Sánchez Hernández JC, Molina JA, Esbrí JM, Lorenzo S. The Almadén district (Spain): anatomy of one of the world's largest Hg-contaminated sites. Sci Tot Env 2006;356:112-24.

Kannan SK, Krishnamoorthy R. Isolation of mercury resistant bacteria and influence of abiotic factors on bioavailability of mercury - a case study in Pulicat Lake North of Chennai, South East India. Sci Tot Env 2006;367:341-53.

Komura I, Funaba T, Izaki K. Mechanism of mercuric chloride resistance in microorganisms: II NADPH-dependent reduction of mercuric chloride and vaporization of mercury from mercuric chloride by a multiple drug resistant strain of Escherichia coli. J Biochem 1971;70:895-901.

Kotnik J, Horvat M, Dizdarevič T. Current and past mercury distribution in air over the Idrija $\mathrm{Hg}$ mine region, Slovenia. Atmos Env 2005;39:7570-9.

Kramer A, Schwebke I, Kampf G. How long do nosocomial pathogens persist on inanimate surfaces? A systematic review. BMC Infectious Diseases 2006;6:130. doi:10.1186/1471-2334-6-130.

Lester ED, Satomi M, Ponce A. Microflora of extreme arid Atacama Desert soils. Soil Biology and Biochemistry 2007;39:704-8. 
Lin CJ, Pehkonen SO. The chemistry of atmospheric mercury: a review. Atmos Env 1999;33:2067-79.

Menéndez A. Un mundo sin sol. La salud de los Trabajadores de las Minas de Almadén, 1750-1900. Biblioteca Chronica Nova de Estudios Históricos. Granada: University of Granada Press; 1996. $318 \mathrm{pp}$.

Molina JA, Oyarzun R, Esbrí JM, Higueras P. Mercury accumulation in soils and plants in the Almadén mining district, Spain, one of the most contaminated sites on Earth. Env Geochem Health 2006;28:487-98.

MSDS Mercuric chloride. MSDS Number: M1469, http://www. jtbaker.com/ msds/englishhtml/m1469.htm, May 2007.

New York Botanical Garden Index herbariorum: A global directory of public herbaria and associated staff http://sciweb.nybg.org/ science2/IndexHerbariorum.asp, May 2007.

Purewal V. The identification of four persistent and hazardous residues present on historical plant collections housed within the National Museum and Galleries of Wales. Collection Forum 2001;16:77-86.
Rader L, Ison C. Legacy of mercury chloride. In: Metsger DA, Byer SC, editors. Managing the modern herbarium, an interdisciplinary approach. Washington DC: The Society for the Preservation of Natural History Collections and The Royal Ontary Museum; 1999. p. 353-4.

Scholtz MT, van Heyst BJ, Schroeder WH. Modelling of mercury emissions from background soils. Sci Tot Env 2003;304:185-207.

Sholupov SE, Ganeyev AA. Zeeman absorption spectrometry using high frequency modulated light polarization. Spectrochim Acta 1995;50B:1227-38.

US EPA. Mercury response guidebook - section $3 \mathrm{http} / / / \mathrm{www} . e p a$. gov/epaoswer/hazwaste/mercury/pdf/chapter3.pdf, May 2007.

US OSHA. Health and safety $(\mathrm{Hg})$. Occupational hazards http://www. hgtech.com/HSE/HSE.htm, May 2007.

WHO. Air quality guidelines for Europe. WHO Regional Publications European Series 91, World Health Organization Regional Office for Europe, Copenhagen (2000), 288pp. 